\title{
Synthesis and Characterization of Natural Sensitizers for Dye Sensitized Solar Cells
}

\author{
Mohammed Isah Kimpa ${ }^{1}$, Kasim Uthman Isah ${ }^{1}$, Jibrin Alhaji Yabagi ${ }^{2}$, Sulaiman Taufiq ${ }^{3}$, \\ Mohd Arif Bin Agam ${ }^{4}$
}

${ }^{1}$ Federal University of Technology Minna

P. M. B. 65, Minna, Nigeria

${ }^{2}$ Ibrahim Badamasi Babangida University Lapai

KM3, Minna Road, Lapai, Nigeria

${ }^{3}$ Umaru Waziri Federal Polytechnics

P. M. B. 1034, Birnin Kebbi, Nigeria

${ }^{4}$ Universiti Tun Hussein Onn Malaysia

101 Beg Berkunci, Parit Raja, Batu Pahat, Johor, 86400, Malaysia

DOI: $10.22178 /$ pos.27-3

LCC Subject Category:

TP155-156, QC450-467, QD450-801

Received 15.09.2017

Accepted 18.10.2017

Published online 20.10.2017

Corresponding Author:

kimpa@futminna.edu.ng

(C) 2017 The Authors. This

article is licensed under a

Creative Commons

Attribution 4.0 License
Abstract. Natural dyes of anthocyanin extract from flame tree flower (Delonix regia) and chlorophyll extract from pawpaw leaf (Carica papaya) were used as sensitizer to fabricate dye sensitized solar cell (DSSC). The photoelectrode were subjected to UV/Vis spectrophotometer to view their absorbability. The photo electrochemical performances of DSSCs obtained from I.V characteristics showed conversion efficiency, ( $\eta$ ) of $0.80 \%$ for the dye extracts from flame tree flower (anthocyanine), with open-circuit voltage $\left(V_{O C}\right)$ of $0.5249 \mathrm{mV}$, short-circuit current density (ISC) of 44.6191 $\mathrm{mA} / \mathrm{m}^{2}$ and Fill factor $(F F)$ of 0.5837 . Chlorophyll dyes extract from pawpaw leaf has $V_{o c}, I s c, F F$ and conversion efficiency, (n) of $0.5249 \mathrm{mV}, 16.5283 \mathrm{~mA} / \mathrm{m}^{2}, 0.5585$ and $0.27 \%$ respectively. The conversion efficiency for the mixed dyes (anthocyanin and chlorophyll) at ratio $1: 2$ is $0.23 \%$ with $V_{o c}$, Isc and FF of $0.5500 \mathrm{mV}, 14.2750 \mathrm{~mA} / \mathrm{m}^{2}$ and 0.5451 respectively, while the dye mixture at ratio $1: 4$ achieved $V_{0 c}$ of $0.5249 \mathrm{mV}$, Isc of $18.4941 \mathrm{~mA} / \mathrm{m}^{2}$, FF of 0.5206 and conversion efficiency (n) of $0.26 \%$. Anthocyanine from flame tree flower dye extract had the higher conversion efficiency of $0.8 \%$ which could be better in term of application in dye solar cell.

Keywords: flame tree flower; pawpaw leaf; solar cell; absorbance; chlorophyll; anthocyanin.

\section{INTRODUCTION}

Dye-sensitized solar cell (DSSC) is a device that change light into electric energy by light sensitization established on wide energy-band semiconductor [1]. Conventionally, solar cells semiconductor has the task of light absorption and the transportation of charge-carrier, whereby in the DSSCs, they are separately controlled [2]. The photosensitizing dye adsorbed on the nanocrystalline $\mathrm{TiO}_{2}$ semiconductor, absorbs light. The ejected electrons excite to the conduction band of the semiconductor leaving the oxidized dye molecules behind [3]. The electrons travel to the counter electrode through the external circuit to reduce the iodide ion of the electrolyte. The iodide ions transport the electrons back to the dye [4].
Among the dye-sensitized solar cells, the dyesensitized solar cell using Ruthenium complex shows a high conversion efficiency of about 11$12 \%$ [5]. However, Ruthenium is a rare metal and the cost of ruthenium complex is very high. On the other hand natural dye is easy to obtain and the cost is very low [6]. Green plants are mostly rich in chlorophyll and red leaves are rich in anthocyanine [7] and the application of this kind of natural dye has been frequently investigated in many related studies $[3,8,9]$.

In this paper, extracts of pawpaw leaves and flame tree flower were the natural dyes used as light sensitizers for the preparation of DSSCs. The conversion efficiency of the DSSCs was investigated via solar simulator. 


\section{MATERIAL AND METHODS}

\section{Preparation of natural dye}

Fresh pawpaw leaves and flame tree flower were separately squeezed to obtained a pure and natural dye solution. Water was used as the extracting solvent. The extract fluid were heated separately for $10 \mathrm{~min}$ to extract chlorophyll from pawpaw leave dye solution and anthocyanine from flame tree flower dye solution. Then, the extract solution of pawpaw leaves and flame tree flower were blended at the ratios of $1: 2$ and 1:4 to serve as natural dye cocktail from these two plants.

\section{Preparation of the $\mathrm{TiO}_{2} /$ Dye Electrode}

The ITO glass $\left(0.03 \mathrm{~cm}^{*} 0.7 \mathrm{~cm}=0.021 \mathrm{~cm}^{2}\right)$ was cleaned with distilled water and acetone to remove impurities. The cleaned ITO surface was coated with commercially available nanocrystalline $\mathrm{TiO}_{2}$ paste using the screen printing method. To improve this situation and increase the compactness of thin film, the $\mathrm{ITO} / \mathrm{TiO}_{2}$ electrodes were sintered at $450{ }^{\circ} \mathrm{C}$ for 1 hour. When the temperature of the $\mathrm{TiO}_{2}$ electrodes reached $80{ }^{\circ} \mathrm{C}$ during cooling, the electrodes were immersed into different dyes solution for 24 hours. The white $\mathrm{TiO}_{2}$ film will change color when dye is adsorbed on the $\mathrm{TiO}_{2}$ electrode. The $\mathrm{TiO}_{2} /$ dye electrode was washed with water and ethanol to remove impurities and trapped water. After cleaning, the DSSCs photoelectrode was complete and ready for testing.

\section{The assembly of DSSCs}

DSSCs were encapsulated according to the general assembly procedures [10]. A DSSC is mainly comprised of ITO conductive glass, $\mathrm{TiO}_{2}$ nanoparticles, natural dye, an electrolyte, counter electrode and spacers. A glass insulation spacer in long strips was initially stuck on the four edges on the base plate of conductive glass at the bottom to create space between photoelectrode and counter electrode and enabling the injection of electrolyte after assembly. AB glue was used to bind the base plate of lower conductive glass carrying the counter electrode with the base plate of upper conductive glass carrying the photoelectrode. The gap between the electrodes was filled with the electrolyte to make the cell complete. This was performed by capillary effect. The process was repeated until the entire internal surface of the cell was completely wetted with the electrolyte. The cell was now complete and operational. Schematic diagram of the molecular structure of the anthocyanine obtained from the red leaf extract of Flame tree flower is shown in Figure $1(\mathrm{a})$ and $1(\mathrm{~b})$.
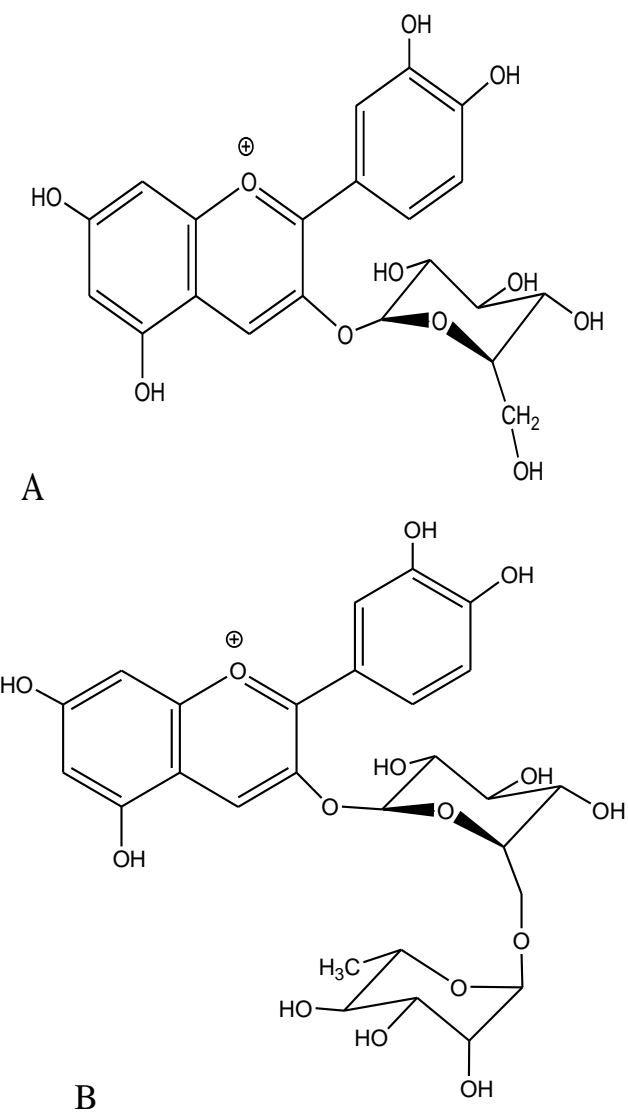

Figure 1-Chemical structure of anthocyanin

(a) - Cyanidine 3-0-rutinoside and

(b) - Cyanidine 3-0-glucoside

\section{Measurement of photoelectric conversion efficiency of DSSC}

The photoelectric conversion efficiency of DSSC was inspected under the simulated sunlight source (A.M 1.5) with current - voltage (I-V) characteristic, the fill-factor $(F F)$ was defined as (1):

$$
F F=\frac{I_{\max } \times V_{\max }}{I_{s c} \times V_{o c}}
$$

where $I_{\max }$ and $V_{\max }$ denote maximum output value of current and voltage respectively, and $I_{S c}$ and $V_{o c}$ denote the short circuit current and open-circuit voltage respectively. The total energy conversion efficiency was defined as (2): 


$$
\eta=\frac{I_{s c} \times V_{o c} \times F F}{P_{i n}}
$$

where $P_{\text {in }}$ denotes the energy of incident photon.

\section{RESULTS AND DISCUSSION}

\section{XRD and SEM analysis}

Figure 2 shows the XRD pattern of the $\mathrm{TiO}_{2}$ nanoparticle. The spectrum is identical to the standard data sheet (JCPD 01-075-8897).

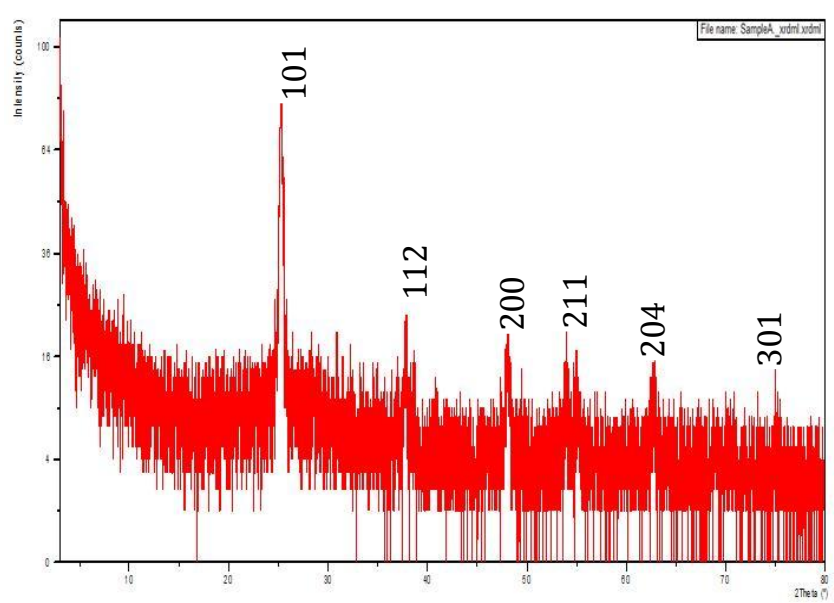

Figure $2-\mathrm{XRD}$ analysis of the anatase $\mathrm{TiO}_{2}$ thin film

The XRD pattern observed in this study is in agreement with previous report [8]. Surface morphology of the $\mathrm{TiO}_{2}$ nanocrystalline is presented in Figure 3, which shows homogeneous and uniform spread of the anatase $\mathrm{TiO}_{2}$ film on the glass substrate.

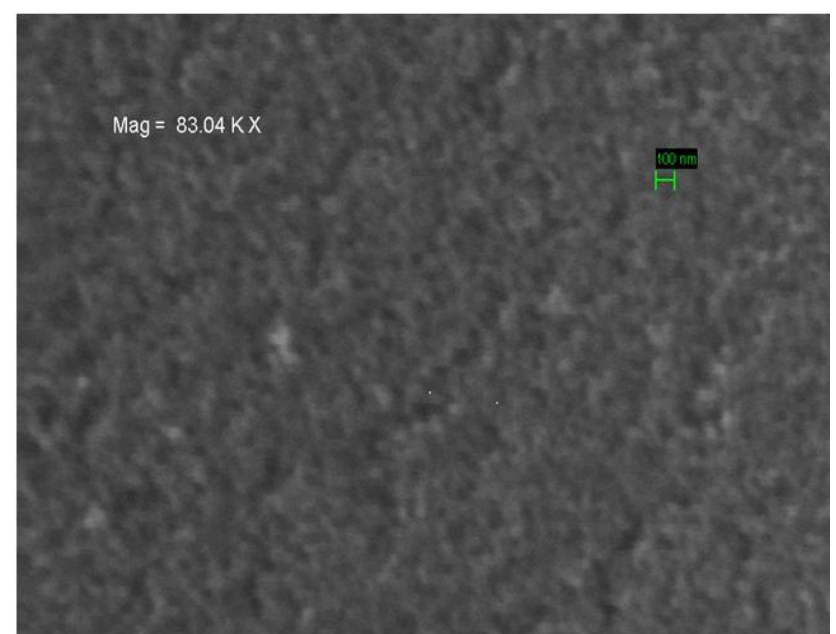

Figure 3 - SEM image of the photo electrode thin film fabricated using screen printing method
The paste was observed to have agglomeration particle size with film porosity which allows electrons to travel and be collected at the surface of the conduction substrate. Figure 4 show the analysis of the elemental composition of $\mathrm{TiO}_{2}$ anatase.

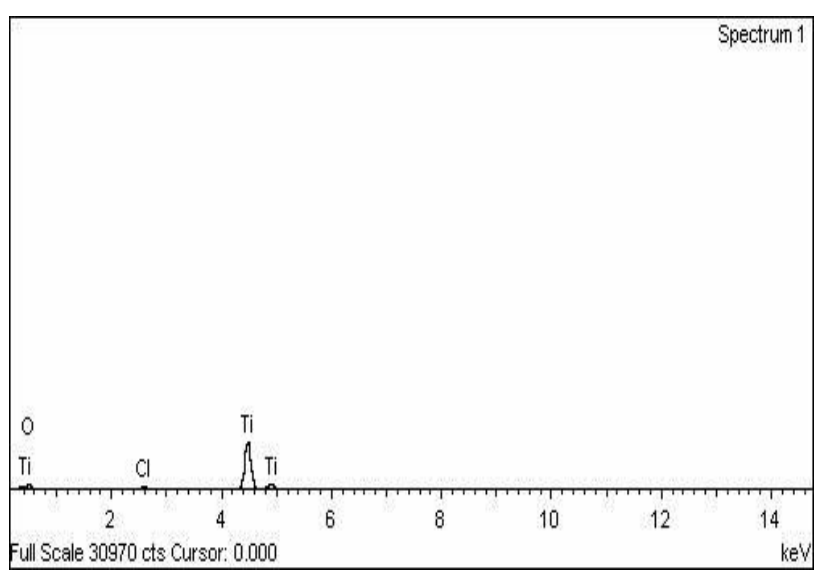

Figure 4 - EDX image of the photo electrode of $\mathrm{TiO}_{2}$

The analysis revealed the presence of titanium, oxygen and very little chlorine. Chlorine was detected in the compound due to $\mathrm{TiCl}_{4}$ that contained in the preparation of anatase $\mathrm{TiO}_{2}$ compound. For any efficient solar cell, the EDX revealed the compound composition of the element it's composed.

Any other element found outside the $\mathrm{TiO}_{2}$ semiconductor compound could degrade the performance of the solar cell.

\section{Absorption of natural dyes}

Figure 5 show the absorption spectra of the pawpaw leaf extracts, mixed dye extracts of pawpaw and flame tree flower at ratio 1:2 and 1:4. The absorption spectrum for the three dyes extract where within the wavelength of 300 to $550 \mathrm{~nm}$ with the maximum peak absorption value at $380 \mathrm{~nm}$ for mixed dyes at 1:4. The difference in absorption peak for different dye extract could be as a result of differences in chemical structure of these pigments.

Figure 6 show the absorption spectra of the flame tree flower and mixed dye extracts at the ratio of $1: 2$ and 1:4. Figure 7 depict the absorption spectra from the extracts of flame tree flower, pawpaw leaf, mixed dyes at 1:4 and 1:2. It was observed in (Figure $6 \& 7$ ) that the absorption range of the dye extracts is between 300$550 \mathrm{~nm}$ with absorption peak at wavelength of $380 \mathrm{~nm}$ for the dye cocktail (mixed dye) at ratio 
(1:2 and 1:4) and flame tree flower while the absorption peak of pawpaw leaf extracts was at $350 \mathrm{~nm}$.

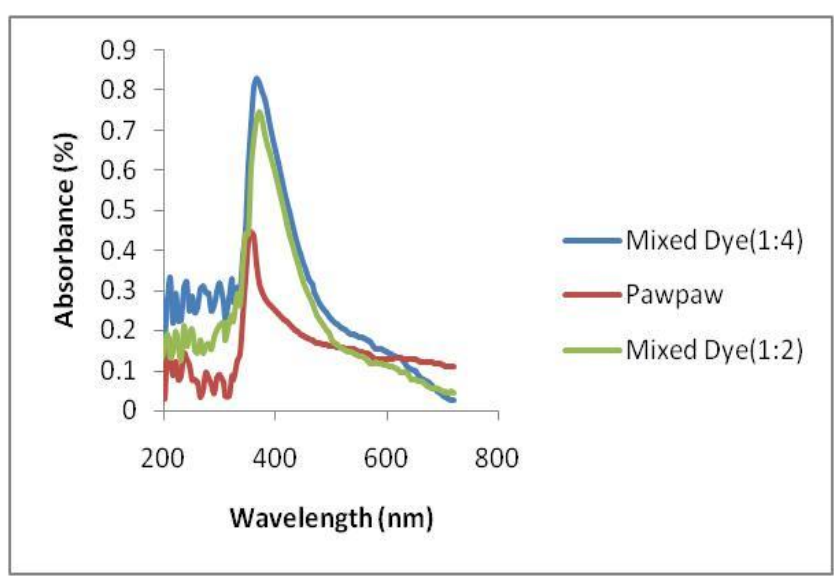

Figure 5 - Absorption spectra of mixed dye extracts at 1:4, pawpaw dye and mixed dye at $1: 2$

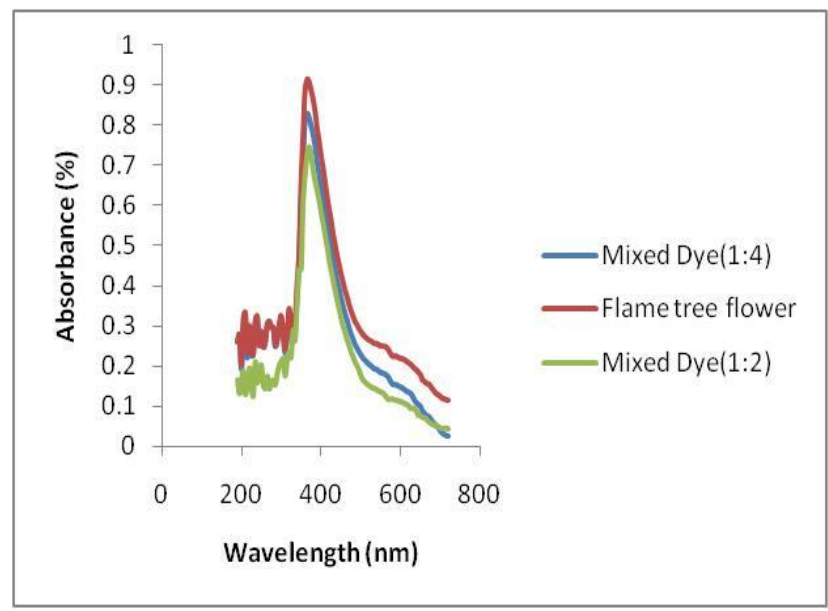

Figure 6 - Absorption spectra of the mixed dyes extracts at 1:2, 1:4 and flame tree flower extracts

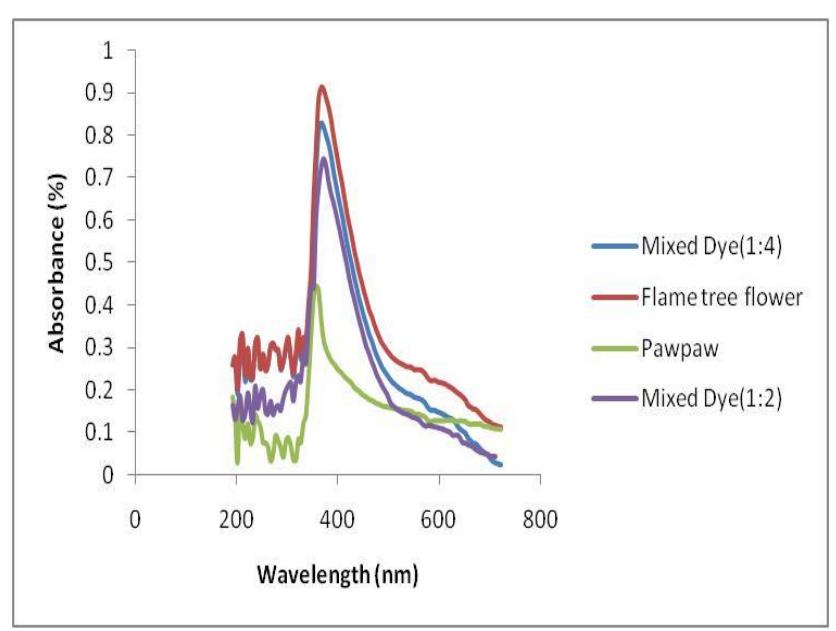

Figure 7 - Absorption spectra of the mixed dye extracts at ratio 1:2, 1:4, pawpaw leaf extract and flame tree flower extracts of DSSC
All the absorption spectrum (Figures 5-7) shows the absorption of the dye extracts within the Ultra-Violet Visible range with the absorption peak at the violet color region that appears greenyellow color as complementary color. Pawpaw leaf dye extracts absorbed light at lower peak than other dye extracts. This could be as a result of the extracting solvent use in this study. Similar work was done by [7] with ethanol as the extracting solvent and pawpaw leaf extract had better absorption peak than flame tree flower extract. Another reason that could lower the absorption peak of pawpaw extract among the study dyes could be due to different absorption properties for different pigments and colors of different extract fluids [8].

Figure 8 shows the photovoltaic test of DSSCs using these natural dyes as sensitizers.

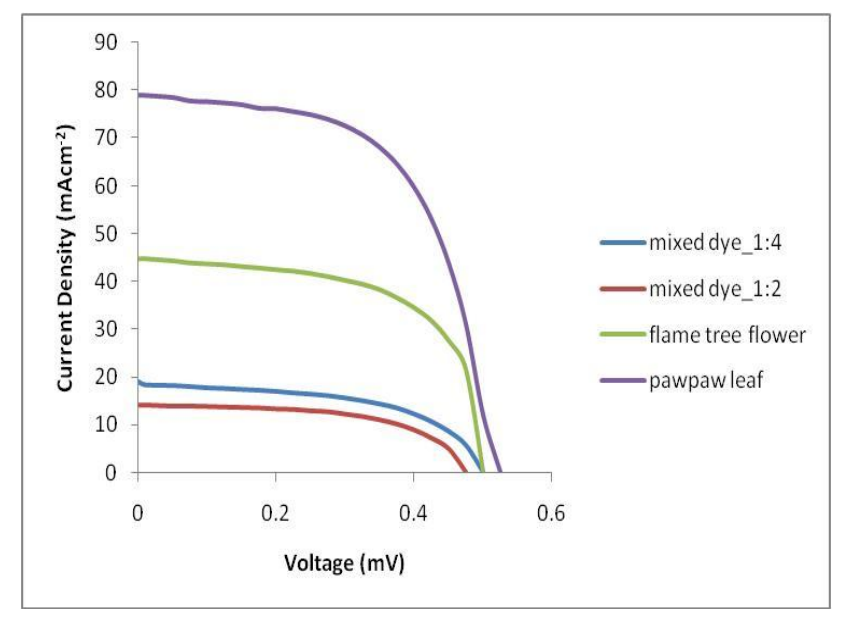

Figure 8 - I-V Characteristic of DSSC sensitized by natural dye extracts from pawpaw leaf, flame flower leaf, mixed dyes at 1:2 and 1:4

Their performances were measured by currentvoltage (I-V) curves under irradiation with halogen lamp $\left(100 \mathrm{mWcm}^{-2}\right)$ from solar simulator. Table 1 shows the data acquired from measuring the photoelectric conversion efficiency of the DSSCs.

Table 1 - Photo electrochemical parameters of the DSSCs sensitized by natural dyes extracted with water in the UV-vis light range

\begin{tabular}{|l|c|c|c|c|}
\hline \multicolumn{1}{|c|}{ Dye } & $\begin{array}{c}\text { Voc, } \\
\mathrm{mV}\end{array}$ & $\begin{array}{c}\text { Isc, } \\
\mathrm{mAcm}^{-2}\end{array}$ & FF & $\eta, \%$ \\
\hline Flame tree flower & 0.5249 & 44.6191 & 0.5837 & 0.80 \\
\hline Pawpaw leaf & 0.5249 & 16.5283 & 0.5585 & 0.27 \\
\hline Mixed dye 1:4 & 0.5249 & 18.4941 & 0.5206 & 0.26 \\
\hline Mixed dye 1:2 & 0.5500 & 14.2750 & 0.5451 & 0.23 \\
\hline
\end{tabular}


From the results obtained, natural dye extracts from flame tree flower had the highest conversion efficiency than pawpaw leaf dye extracts and the cocktail dye extracts that were blended in two different ratios (1:2 and 1:4). This could be as a result of the chlorophyll extracts from pawpaw leaf and the extracting solvent (water). More also the blended ratio could also be the reason for their lower efficiencies because the anthocyanine dye extracts from flame tree flower that shows the highest conversion efficiency was the dye extracts that was added to the chlorophyll dye extracts at different ratio, chlorophyll was kept constant. Another reason for their lower efficiencies could also be from their absorbability capacity.

Furthermore, Table 1 compares different property parameters of DSSCs using different natural dyes, including short-circuit photo current density (Jsc), open-circuit voltage (Voc), fill factor (FF) and energy conversion efficiency ( $\eta$ ). As shown in Table 1, the photoelectric conversion efficiency of flame tree flower extract fluid is higher than the photoelectric conversion efficiency of the extracts from pawpaw leaf and the dye mixtures at ratio $1: 2$ and 1:4. This is because the absorption intensity of flame tree flower is higher than the other dye extracts. In addition, DSSCs fabricated from the extracts of flame tree flower had better charge-transfer performance and clearly improved efficiency to $0.8 \%$. Figure 9 shows the power against voltage curves of the DSSCs using the natural dyes extracted from the pawpaw leaf, flame tree flower, mixed dye at ratio $1: 2$ and 1:4.

The DSSC using natural dye extracts from flame tree flower has the maximum power rate of about $13.6704 \mathrm{~mW}$.

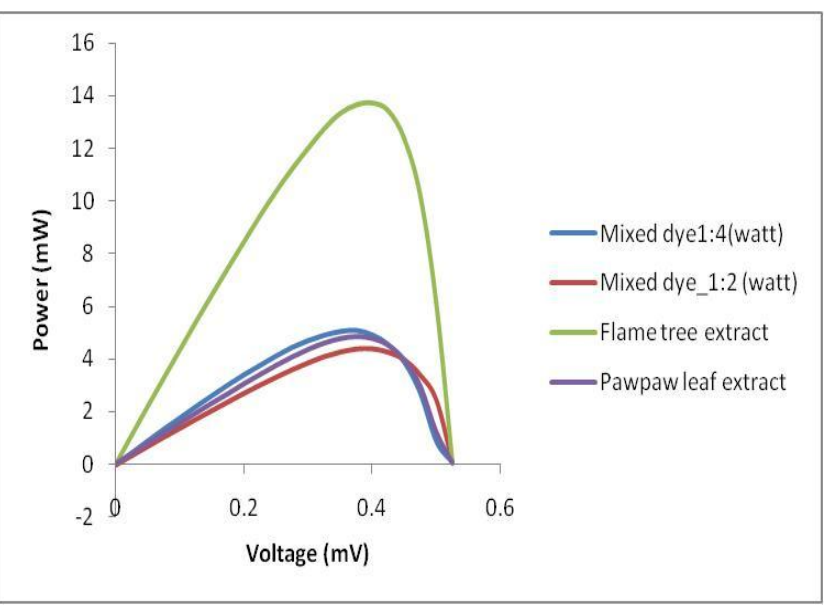

Figure 9 - Plot of power against voltage for DSSC sensitized by natural dyes extracts from pawpaw leaf, flame tree flower, mixed dyes at ratio 1:2 and 1:4

\section{CONCLUSION}

The measurement and analysis of the absorption spectra for natural dyes extracted from the pawpaw leaf, flame tree flower, mixed dye at $1: 2$ and 1:4 are carried out. The results show that the dye extracted from the flame tree flower has similar absorption spectrum to the dye extracts for the pawpaw leaf and their mixed dyes which has absorption wave band at 300-550 nm. The DSSC using the flame tree flower dye extracts has the best photo electric conversion efficiency of $0.80 \%$ and has the maximum power of about $13.6704 \mathrm{~mW}$.

\section{ACKNOWLEDGMENT}

The authors would like to thank the entire staff of the Physics Advanced Lab, Sheda Science and Technology Complex (SHESTCO) Abuja for allowing us to use their laboratory.

\section{REFERENCES}

1. Chang, H., Kao, M.-J., Chen, T.-L., Kuo, C.-G., Cho, K.-C., \& Lin, X.-P. (2010). Natural Sensitizer for DyeSensitized Solar Cells Using Three Layers of Photoelectrode Thin Films with a Schottky Barrier. American Journal of Nanotechnology, 1(1), 13-22. doi: 10.3844/ajnsp.2010.13.22

2. Osman, U. M., Farizal, A. S. N., Razali, M. H., \& Salleh, H. (2017). Synthesis of Nano Crystalline 1-[2(Trifluoro-Methyl) Benzylidene] Thiosemicarbazide with D- $\pi$-A Architecture towards Dyes Sensitized Solar Cells. Journal of Engineering and Applied Sciences, 12(9), 2506-2511.

3. Isah, K. U., Ahmadu, U., Idris, A., Kimpa, M. I., Uno, U. E., Ndamitso, M. M., \& Alu, N. (2014). Betalain pigments as natural photosensitizers for dye-sensitized solar cells: the effect of dye $\mathrm{pH}$ on the photoelectric parameters. Materials for Renewable and Sustainable Energy, 4(1). doi: 10.1007/s40243-014-0039-0 
4. Pradhan, B., Batabyal, S. K., \& Pal, A. J. (2007). Vertically aligned ZnO nanowire arrays in Rose Bengalbased dye-sensitized solar cells. Solar Energy Materials and Solar Cells, 91(9), 769-773. doi: 10.1016/j.solmat.2007.01.006

5. Zhou, H., Wu, L., Gao, Y., \& Ma, T. (2011). Dye-sensitized solar cells using 20 natural dyes as sensitizers. Journal of Photochemistry and Photobiology A: Chemistry, 219(2-3), 188-194. doi: 10.1016/j.jphotochem.2011.02.008

6. Furukawa, S., Iino, H., Iwamoto, T., Kukita, K., \& Yamauchi, S. (2009). Characteristics of dye-sensitized solar cells using natural dye. Thin Solid Films, 518(2), 526-529. doi: 10.1016/j.tsf.2009.07.045

7. Isah Kimpa, M., Momoh, M., Uthman Isah, K., Nawawi Yahya, H., \& Muhammed Ndamitso, M. (2012). Photoelectric Characterization of Dye Sensitized Solar Cells Using Natural Dye from Pawpaw Leaf and Flame Tree Flower as Sensitizers. Materials Sciences and Applications, 03(05), 281-286. doi: 10.4236/msa.2012.35041

8. Chang, H., Wu, H. M., Chen, T. L., Huang, K. D., Jwo, C. S., \& Lo, Y. J. (2010). Dye-sensitized solar cell using natural dyes extracted from spinach and ipomoea. Journal of Alloys and Compounds, 495(2), 606-610. doi: 10.1016/j.jallcom.2009.10.057

9. Nair, G., Ramli, S., Irwanto, M., Yusoff, M. I., Fitra, M., Hashim, U., \& Mariun, N. (2014). Fabrication of Organic Dye Sensitized Solar Cell. Applied Mechanics and Materials, 699, 516-521. doi: 10.4028/www.scientific.net/amm.699.516

10. Kimpa, M. I. (2012). Fabrication and Analysis of Dye-Sensitized Solar Cells Using Natural Dyes Extracted from Pawpaw Leaf and Flame Tree Flower and their Synthetic Ruthenium Dye (Master's Degree Dissertation). Sokoto: Usmanu Danfodiyo University Sokoto. 